\title{
Article
}

\section{Passion in the Workplace: Empirical Insights from Team Sport Organisations}

Anagnostopoulos, Christos, Winand, Mathieu and Papadimitriou, Demetra

Available at http://clok.uclan.ac.uk/15044/

Anagnostopoulos, Christos ORCID: 0000-0001-7470-5191, Winand, Mathieu and Papadimitriou, Demetra (2016) Passion in the Workplace: Empirical Insights from Team Sport Organisations. European Sport Management Quarterly, 16 (4). ISSN 1618-4742

It is advisable to refer to the publisher's version if you intend to cite from the work. http://dx.doi.org/10.1080/16184742.2016.1178794

For more information about UCLan's research in this area go to http://www.uclan.ac.uk/researchgroups/ and search for <name of research Group>.

For information about Research generally at UCLan please go to http://www.uclan.ac.uk/research/

All outputs in CLoK are protected by Intellectual Property Rights law, including Copyright law. Copyright, IPR and Moral Rights for the works on this site are retained by the individual authors and/or other copyright owners. Terms and conditions for use of this material are defined in the policies page. 


\section{Passion in the Workplace: Empirical Insights from Team Sport Organisations}

Research Question: Although sport management scholars have focused on a fairly wide number of psychologically-related constructs in the workplace, passion has not been part of this research agenda. The present study is the first attempt to fill this gap by exploring employees' passion in the workplace setting of sport organisations. It does so by applying for the first time the dualistic model of passion developed by Vallerand et al. (2003), which measures two distinct types of passion: harmonious and obsessive.

Research Methods: Online survey data were gathered from administrative employees in the United Kingdom's football industry, responsible for either business-related functions or the clubs' social agenda $(\mathrm{N}=236)$ in order to measure the passion experienced by individuals guided by different institutional logics. The particular instrument has two components: harmonious and obsessive passion towards the job. Besides the passion scales, the survey contained measures related to demographic variables (e.g., age, gender and education), to employment position in the organisation and to previous job experience. Data were statistically analysed in Confirmatory Factor Analysis (CFA) and analysis of variance, using SPSS and Amos 18.0. To determine the effect of contextual variables on the passion for the job, t-test and ANOVA were also used.

Results and Findings: Both groups of employees are passionate about their job. They remain harmoniously passionate throughout their career and show low level of obsessive passion. The type of work activities influences both levels of harmonious and obsessive passion experienced by personnel within sport organisations with employees responsible for the social agenda being slightly more harmoniously and obsessively passionate compared to those responsible for the business agenda.

Implications: Vallerand et al.'s (2003) dualistic model of passion has been adapted to measure passion at workplace within sport organisations. The particular working environment that forms these organisations attracts and/or facilitates employees to experience a positive work-life balance.

Keywords: passion at work, sport organisations, dualistic model of passion,, football 
Passion is a fascinating psychological construct (Gielnik et al., 2015), which has been generally defined as a strong inclination towards an activity that people like and find important, and in which they invest time and energy (Vallerand et al., 2003). Given that work is one of the most important activities in a person's life (Birkeland \& Buch, 2015; Houlfort \& Vallerand, 2006; Perttula \& Cardon, 2011), passion has been recently the subject of examination in the context of the workplace at both the conceptual (e.g. Zigarmi et al, 2009; Vallerand \& Houlfort, 2003) and empirical levels (Caudroit et al., 2011; Forrest, Mageau, Sarrazin, \& Morin, 2011; Ho, Wong, \& Lee, 2011; Marques, 2007; Neumann, 2006; Patel, Thorgren, \& Wincent, 2015; Thorgren, Wincent, \& Sirén, 2013). Practitioners, too, have emphasized both the personal benefits of being passionate about one's job (Anderson, 1995; Boyatzis, McKee, \& Goleman, 2002), and the organisational gains that result from companies having passionate employees (Bruch \& Ghoshal, 2003; Moses, 2001). At personal level, for example, passion at work results in lower levels of job burnout (Vallerand et al., 2010), better quality of interpersonal relations (Philippe et al., 2010) as well as satisfaction at work (Thorgren et al., 2013; Vallerand, Paquet, Philippe, \& Charest, 2010). From the organisations' perspective, passionate workforce lead to greater employee creativity and effectiveness (Perttula \& Cardon, 2011), and to higher performance under challenging situations (Patel et al., 2015).

In the context of sport, however, despite that there are as many as 6 million sportrelated jobs in sales, marketing, administration, and media in the United States (Shank \& Lyberger, 2015) and about 450,000 in the United Kingdom (Cave, 2015), the examination of passion at work has been inexistent. Interestingly, studies have found that employees outside the sport industry were more satisfied with their compensation than were persons working in sports (Parks, 1991; Parks \& Para, 1994), thereby suggesting that the intention to enter the sport management profession is not guided by remuneration alone (Cunningham \& Sagas, 
2004; Sibson, 2010). Such desire for working in the sport industry may be generally justified by the specificity (Hassan, 2012; Smith \& Stewart, 2010) and idiosyncratic characteristics (Day, Gordon, \& Fink, 2012) of the industry itself. That is, the passion for sport the very same employees experience as passive or active consumers (Smith \& Stewart, 2010; Wakefield, 2016) and/or through their identification and involvement with a sport team (Todd \& Andrew, 2008). Indeed, recent empirical studies have shown that the employees of team sport organisations are distinct from those in other industry sectors, in that they identify both with the parent organisation in which they are employed and the team that represents the organisation (Oja, Bass, \& Gordon, 2015; Swanson \& Kent, 2015). Job seekers, therefore, are largely attracted to jobs in sport industry because they perceive a good fit between their preferences for future work and the sporting environment (Todd \& Andrew, 2008).

However, studies examining passion at workplace have empirically shown that depending on how people identify with their work, their passion can take on more adaptive (harmonious) or maladaptive (obsessive) forms that facilitate or impede their work-life balance (Vallerand, 2015). Passion, therefore, is seen as distinct from related constructs possessing proactivity, enthusiasm, persistence, and focus (Perrewé et al., 2014). In other words, some of the job-related constructs that have been examined in sport management literature such as organisational or occupational commitment of intercollegiate coaches (e.g., Chelladurai \& Ogasawara, 2003; Turner \& Chelladurai, 2005) or sporting goods retail employees (Todd \& Andrew, 2006), employees' satisfaction (e.g., Cleave, 1993; Hall, Bowers, \& Martin, 2010; Parks \& Para, 1994) and/or burnout (e.g., Danylchuk, 1993) offer a one-dimensional perspective, which makes them difficult to use when one attempts to theoretically explain not only the positive, but also the possible dark sides of enjoying work (Thorgren et al., 2013). 
More specifically, beyond passion's positive association with greater work satisfaction (Carbonneau, Vallerand, Fernét., \& Guay, 2008), mental health (Forest et al., 2011), and subjective well-being (Rousseau \& Vallerand, 2008), passion may also lead to uncontrolled rumination (Ratelle et al., 2004) and inflexibility (Vallerand et al., 2003). Moreover, passionate employees may showcase aggressive behaviour associated with active pursuit of goals, the elimination of barriers, and the accumulation of job-related materials and support (Cardon et al., 2009). Thus, the behaviour of passionate employees may be interpreted as threatening, particularly when work resources are perceived as finite (Perrewé et al., 2014). Finally, compulsive levels of passion can lead to a level of rigid persistence that hinders task completion and interpersonal relationships with others in the organization (Vallerand et al., 2010).

\section{Rationale and research questions}

Given the conceptual characteristics that passion at workplace entails, the present study is set to examine passion in the context of sport organisations and contribute to the extant sport management literature in three ways. First, prior studies have accentuated that social-identity theory (SIT) plays a prominent role in the context of sport, from the perspective of consumers (Wann \& Branscombe, 1993) and employees (Todd \& Kent, 2009) alike, thereby underlying the distinctiveness of sport from other industrial settings (Smith \& Stewart, 2010). The present study acknowledges that work for a passionate employee becomes part of his/her identity (Vallerand et al., 2003) and that such activity can motivate this person to identify with others with a shared passion. Though given that "passion is an individual determinant of relevant behaviour and group identification is a likely, but not necessary, corollary" (Wakefield, 2016), we extend the theoretical discussion in the sport workplace by drawing on self-determination theory (SDT; Deci \& Ryan, 2000) and the dualistic model of passion (DMP; Vallerand et al., 2003) to examine whether passion 
manifests in sport organisations' workforce. According to SDT, an individual grows psychologically when also connects him/herself to others within a social context. This 'relatedness' (Deci \& Ryan, 2000) echoes what Ashforth and Mael (1989) refer to as organisational identification, which is a specific form of social identification where members define themselves in terms of the organisation as a social category (Swanson \& Kent, 2015). Such organisation can be the workplace where a person feels the need to be authentically associated and to belong with significant others while carrying out his/her job about which is passionate.

Second, the study responds to calls that future research should identify determinants towards passion at work in the organisational environment that either favours one type of passion over the other (Houlfort \& Vallerand, 2006), or simply leads to higher levels of harmonious passion (Balon, Lecoq, \& Rimé, 2013). Such determinants may relate to the possibility of employees developing different forms of passion depending on the job they undertake even within the same organisational environment (Day et al., 2012). Put differently, given that modern (European) professional teams are constituted by a multitude of institutional logics which reflect the variety of job roles therein (Gammelsæter, 2010), we compare the construct of passion between administrative employees responsible for the teams' 'business operations' and their counterparts who have been assigned the responsibility for the 'social agenda'. The common denominator that both groups share is the logic of professionalism, which means that control of work is based on expertise (Freidson, 2001). However, at the outset, these two groups of employees seem to be qualitatively dissimilar since their jobs do not necessarily share common goals and therefore serve different purposes. In institutionalism parlance, personnel responsible for functions including social media marketing, retailing and merchandising, sponsorship or new and international business development is closer to the managerialism logic that seeks commodification, profitability 
and shareholder value (Gammelsæter, 2010). The latter group of employees, which by and large, carry out its work through the charitable foundations that professional teams have now established (Anagnostopoulos, Byers, \& Shilbury, 2014; Babiak \& Wolfe, 2009) is closer to the logic of idealism and mobilises personnel for higher order goals such as health improvement, promoting alternative educational methods, increasing sports participation, or encouraging social inclusion (Anagnostopoulos \& Shilbury, 2013). Given, therefore, that modern team sport organisations seem to carry different logics expressed through (but not solely) the tasks performed by their workforce, the application of DMP in those two groups of employees may shed light on whether such contradictory logics affect the way passion is manifested within the workplace in question.

Third, taking into account Doherty's (1998) advice that "the focus should be on the relationships among variables, rather than purely descriptive accounts of individual and group characteristics, attitudes, and behaviours" (p. 7), we explore the potential effect of contextual variables on employees' passion for work from both groups of employees. To this end, the present study, which is explorative in nature, sets out to address the following research questions (RQs):

1. Do paid administrative personnel in the context of sport organisations experience passion for their jobs?

a. If so, what type of passion (harmonious or obsessive)?

2. Is there any difference in passion and its types between personnel responsible for the 'business operations' and from those responsible for the team's social agenda?

3. At both the organisational and personal levels, do selected contextual elements (such as level of experience, age, and education) influence the type of passion experienced by paid personnel in both groups of employees? 
This introduction is followed by an outline of the theory that underpins the study, before a discussion on how passion differs from other job-related constructs. Next, a detailed account of the method employed is outlined, and the findings obtained from the empirical analysis are then presented. We conclude with a discussion of the findings, before offering some practical implications and outlining the study's limitations and issues for further research.

\section{Theoretical and conceptual background}

\section{Seld-determination theory}

Self-determination theory (SDT) theoretically underpins this study, which is broadly situated in the field of human motivation. The central premise of SDT is that a person's psychological growth comes from the satisfaction of three basic needs: relatedness, competence and autonomy (Deci \& Ryan, 1985, 2000). According to Deci and Ryan (1994), “people are inherently motivated to feel connected to others within a social milieu, to function effectively in that milieu and to feel a sense of personal initiative while doing so" (p. 7). In other words, the fulfillment of these three psychological needs occurs as a person interacts with the environment and engages in several activities. Therefore, the experience gained from such activities helps the individual grow and develop a sense of self (Gagné \& Deci, 2005).

According to SDT the internalization of elements from the person's environment through such activities can either be an autonomous or a controlled process. In the former, the individual freely accepts the activity as being significant without any attached contingencies. This type of internalization stems from the intrinsic and integrative tendencies of the self (Deci \& Ryan, 2000; Ryan \& Deci, 2000) and yields a motivational force to engage in the activity willingly, thereby stimulating a sense of volition and personal endorsement about pursuing the activity (Vallerand et al., 2003). Put simply, instead of feeling obliged to engage 
in the activity, the individual freely chooses to do so. In contrast, controlled internalization involves various pressures of social acceptance, self-esteem, and similar ego-invested selfstructures (Hodgins \& Knee, 2002).

It is the aforementioned internalization process of SDT upon which Vallerand and his colleagues (2003) conceptualized the construct of passion through the Dualistic Model of Passion (DMP). The central premise of the DMP is that an individual - in endeavouring to satisfy the basic psychological needs of relatedness, competence, and autonomy - engages in enjoyable activities that he or she values highly. These activities become so self-defining that they ultimately represent central features of this person's identity. Such internalization of any given activity within the person's identity will result in a passion for that particular activity. Vallerand and Houlfort (2003) argued that work is one of the most important activities in a person's life, considering that most individuals engage in work-related activities from their early years (schooling) until even after formal retirement. Therefore, since work "serves to define us $[\ldots]$ we are not only people who work in computers, management, or sales, we are computer analysts, managers, or salespersons" (Vallerand \& Houlfort, 2003, p. 176). For many people, work serves an important intrapersonal function that becomes part of their identities and causes them to be passionate about the particular activity. However, according to the DMP (Vallerand et al., 2003), there are two different types of passion - harmonious and obsessive - that describe different concepts, and an employee may have one type but not the other (Ho et al.,, 2011).

The DMP uses the autonomous and controlled internalization processes (Deci \& Ryan, 2000) in the self to explain these two distinct types of passion. Obsessive passion, on one hand, is associated with a pressured internalization of the job, meaning that employees perceive their jobs as important because of certain pressures or outcomes attached to the job (Vallerand \& Houlfort, 2003). For example, an individual may receive a sense of prestige 
and/or self-worth from doing a job, but feel compelled to pursue the activity in a rather rigid form in order to maintain self-worth. Consequently, the job controls the person and becomes an obsession, which may conflict with other aspects of life (Ho et al., 2011). Harmonious passion, on the other hand, entails autonomous and voluntary internalization in which the individual freely and voluntarily pursues the activity or job because of the job's importance or characteristics rather than because of any derived feelings of social approval or recognition (Ho et al., 2011; Vallerand \& Houlfort, 2003).

To illustrate these two distinct types of passion, consider the example of two graphic designers who work for sports teams. Both devote themselves to their jobs in a passionate manner, but internalize this passion for different reasons. One may simply enjoy developing creative ideas and concepts used for marketing purposes (harmonious passion), whereas the other may enjoy the fact that other colleagues value the skills the individual brings to the job and enjoy being relied upon for the (sports team's) marketing and advertising campaign (obsessive passion). The first graphic designer does not experience any guilt when not engaging in job-related activities unless he needs to do so, whereas the other one feels bound to pursue job-related activities even in the presence of non-work commitments and obligations (Ho et al., 2011).

Moreover, the way Vallerand and colleagues (2003) conceptualized passion has set it apart from previously established job-related constructs. The next section elucidates why this is the case in relation to relevant sports management literature.

\section{Passion versus job-related constructs in sport management}

Scholarship in sports management has increasingly emphasized such psychologically-related constructs in work as motivation, satisfaction, commitment, involvement and identification, flow, burnout, and workaholism. However, several other studies have either theoretically 
argued or empirically shown that passion has some important distinctions from these constructs (e.g. Caudroit et al., 2011; Forrest, et al., 2011; Ho et al., 2011; Marques, 2007; Neumann, 2006; Vallerand \& Houlfort, 2003; Vallerand et al., 2010; Zigarmi et al., 2009).

For example, although passion is closely linked to intrinsic motivation (in that both encompass the element of liking an activity), intrinsically-motivated employees are typically not seen as having internalized their work in their identity, which means that the activity does not define them (Deci \& Ryan, 1985). Rather, intrinsically-motivated activities emerge from the short-term person-task interaction (Koestner \& Losier, 2002); that is, employees perform a specific job because it brings immediate pleasure and satisfaction.

The 'distance' between passion and extrinsic motivation is even larger, considering the possible absence of enjoyment for the job itself and the dominance of external reasons (Vallerand, 2010), such as monetary compensation, benefits, or workplace promotion (Chang, Choi, \& Kim, 2008). Beyond such 'tangible' external pressures, Melton and Cunningham (2014) showed that lesbian, gay, bisexual, or transgender (LGBT) employees are motivated by the fact that the sports organisation setting enhances their self-esteem and, by and large, provides greater social acceptance in their working environment. However, Melton and Cunningham's study did not reveal whether LGBT employees actually internalized the working tasks such that they were passionate about their jobs.

Passion in the workplace has also been differentiated in terms of both organisational and occupational commitment. For example, sport management scholars who have examined organisational commitment in relation to several other factors - leadership (Kent \& Chelladurai, 2001), part- and full-time workforce citizenship (Chang \& Chelladurai, 2003) and intention to leave and perceived performance (Turner \& Chelladurai, 2005) - have emphasized the employee's attitude toward the organisation rather than toward the job itself, which pertains to passion. Being passionate about innovative marketing ideas for a sports 
organisation may prompt an employee to work for another organisation (thereby demonstrating low organisational commitment), or to be strongly committed to his or her existing employer (and also be a loyal fan) without necessarily having a passion for the jobrelated tasks. Moreover, employees who are committed to their occupations (such as coaching personnel in Turner and Chelladurai [2005]) may not necessarily like their job activities (Vallerand, 2010). To illustrate, a team's equipment manager (also known as kit person) may demonstrate high commitment for maintaining the athletes' apparel and having everything ready for training sessions and games, but may not enjoy the actual job.

Furthermore, the construct of passion must be distinguished from job satisfaction. This is because passion is not limited to merely liking a job, and also encompasses identification. In contrast, an employee may feel satisfied (or dissatisfied; see Dixon \& Warner, 2010) simply because of pleasant working conditions, good relations with colleagues and supervisors (Cunningham et al., 2005; Hall et al., 2010), or even the job design itself (Cleave, 1993). For example, in one of the first studies to examine a job-related construct in sports administration, Koehler (1988) found that female corporate fitness managers were generally satisfied with their jobs. Interestingly, although the managers' sense of social service and moral values were the most important factors in their high satisfaction levels, which implied cognitive elements behind the pursuit of the task, the study revealed little about whether the managers had internalized their job as part of their identities. To reinforce the point, Parks and Para (1994) found no differences in job satisfaction between sports management alumni who worked in the sports industry and those who did not. However, this finding may not necessarily mean that both groups demonstrate the same passion for their jobs.

Job involvement and identification are two other dimensions of work-related attitudes that are distinct from passion (Vallerand et al., 2003). As mentioned, passion is not only 
cognitive (capturing the importance of the job for the individual), but also affective (having a strong inclination for and enjoyment of the job). In contrast, Kanungo $(1979,1982)$ eschewed the affective aspects of job involvement, stressing its purely cognitive nature, thereby 'capturing the cognitive state of psychological identification' (Ho et al., 2011, p. 29). In other words, an individual may identify with a job as a sport agent or a financial manager for a professional team and find the job important (job identification), but not like or have an interest in pursuing that specific job (a job passion).

Todd and Kent (2009) theoretically proposed, through their positive social identity model, that employees in team sport organisations identify not only with the team, but also with the organisation itself. This idea was empirically tested by Swanson and Kent (2015), who drew on social identity theory that posits that a person's identity and behaviour shift along a personal-collective continuum as a function of social context (Ashforth \& Mael, 1989; Tajfel, 1978; Tajfel \& Turner, 1986). Thus, employees in the sport industry may be expected to identify with a team sport organisation when it is contextually salient to do so. In contrast, passionate employees typically identify with the object of their passion (in this case, the specific job they pursue) because it is accessible and salient at all times, albeit in qualitatively different ways for harmonious versus obsessive passion (Rip, Vallerand, \& Lafrenière, 2012).

In summary, the present study focuses on passion in the workplace in order to understand this motivation-related construct in the context of paid administrative workers within team sport organisations and their subsidiary charitable foundations. This endeavour seeks to support arguments for why the sport industry may be a desirable workplace, thereby offering insights into how human resource development (HRD) units within a sport organisation can realize both 'healthier' and more productive employees. 


\section{Method}

\section{Participants and procedures}

Participants in the study were employees from the British football sector who either worked for the 'parent' club or its charitable foundation. Employees in the former are responsible for business-related matters (e.g., marketing, sponsorship, communication etc.), whereas workforce within the foundations is responsible for formulating and implementing community-based programs that, by and large, fall within the parent's club's wider corporate social responsibility agenda. We developed a database of potential respondents in four interconnected stages. First, we perused the official websites of both organisational unitss and recorded the names, job titles, and contact details of the staff members listed. Second, the lead author used a professional online social network to connect with employees who had a presence in the network and agreed to the connection. Although connecting through this online platform delayed data collection (some 'invitations to connect' were accepted after three months), it did establish necessary professional rapport because the participants were given the opportunity to check the researcher's credentials. Through these connections, the lead author was able to identify and approach additional potential participants (stage 3) whose profiles did not appear on the teams' or foundations' webpages. Last, we also asked those participants who took part in the study to provide contacts (from both the 'parent' club and the foundation) who would be willing to participate in this research. Thirty nine additional contacts has been the result of this call. Although this four-stage process was by no means representative, it resulted in a total of 658 sport employees in various managerial and administrative roles, 456 of whom were employed by professional football clubs and 202 of whom were employed by their affiliated foundations. Athletic and medical staff members, such as players, coaches, physiotherapists or personnel working in the football academies, were excluded from this study. Therefore, the operating core of a professional sport 
organisation (Kent \& Chelladurai, 2001; Mintzberg, 1980) was not considered; rather, the study's participants are close to what Oja and colleagues (2015) defined as middle management in sport.

Following approval from the lead author's university ethical review committee, we sent each of the 658 employees a personal email invitation to take part in the study. Each potential participant received a cover letter describing the purpose of the study and a link to a survey created with Qualtrics online survey software. The survey remained open from April 24, 2014 until July 1, 2014. Three follow-up emails were sent to all non-respondents during the data collection period to increase the response rate. In addition, respondents had the option to receive a copy of the results (45 percent of participants chose this option). Participants' identifying information was kept separate from survey responses to ensure anonymity and confidentiality.

Among the 198 surveys returned, 21 were incomplete and were eliminated, reducing the usable sample to 177, which represents a response rate of 27 percent. Among the completed questionnaires, 70 (39.5 percent) were from foundations' staff and 107 (60.5 percent) were from professional football clubs' staff. These respondents represented 34 different football clubs (42.5 percent of the total number of clubs targeted in England and Scotland) and 53 different community units and/or charitable foundations (66.25 percent).

\section{Instrumentation}

We measured passion using an instrument that Vallerand et al. (2003) developed to gauge the passion individuals experience in different contexts (see Appendix 1). This instrument reflects the dualistic model of passion which is broadly and consistently used into the literature over the last 10 years or so (i.e., Forest et al., 2011; Ho et al., 2011; Vallerand et al., 2008). Curran et al. (2015) in a recent meta-analysis review on passion, have reported 94 
studies which measured passion based on this dualistic model. The particular instrument has two components: one that distinguishes between passionate and non-passionate employees, and one that distinguishes between harmonious or obsessive passion among employees. To distinguish passionate employees, respondents were asked to report their level of agreement with the following statement: 'This job is a passion for me'. They used a five-point Likert scale in which 1 represented 'strongly disagree' and 5 represented 'strongly agree'. Following Vallerand and Houlfort's (2003) recommendation, employees were considered passionate towards their work only if their score was above the midpoint (3) on this scale.

The main part of the instrument consisted of two subscales based on Vallerand et al. (2003) which assess harmonious and obsessive passion, also using a five-point Likert scale. Harmonious passion is measured with a subscale of six items, including 'This job is a passion that I manage to control', 'My job is well integrated in my life', and 'This job allows me to live a variety of experiences'. We used Cronbach's $\alpha$ to estimate the internal consistency of this particular subscale and obtained a value of .74. The instrument subscale measures obsessive passion with such items as 'This job is the only thing that really excites me', 'I am emotionally dependent on this job', and 'This job is so exciting that I sometimes lose control over it'. We found the reliability of the six-item obsessive passion scale to be 0.76 . Previous authors have also reported satisfactory Cronbach's alpha values for harmonious (.71-.84) and for obsessive passion (.60.-.87) supporting the reliability of the particular two sub-scales (Vallerand et al., 2003; Vallerand \& Houlfort, 2003). In addition, a number of studies have supported the construct validity of the particular instrument in different contexts including work (Vallerand and Houlfort, 2003; Carbonneau et al., 2008). The above provide adequate evidence that the passion conceptualization with the 12 item scale grouped into two 6-item sub-scales (i.e., harmonious and obsessive passion) is a valid and reliable instrument. Overall, the final instrument consisted of 13 items measuring the respondents' harmonious (i.e., six 
items), obsessive passion (i.e., six items) and overall passion (i.e., the passion criterion). The only change made in the original instrument was on the term "this activity" which was used by Vallerand et al. (2003) and it was substituted for the needs of present study with the term "this job" to fit the context of the present study. Respondents were consistently provided with a 5-point Likert scale ranging from 1- "strongly disagree", to 5 -"strongly agree", to check their responses.

The survey also collected demographic variables (age, gender, and education), employment position in the organisation, and previous experience in the current role, both in the specific organisation and in sport industry in general. Finally, respondents were asked to indicate their organisation's type (football club or charitable foundation) and the organisation size (number of employees). The above variables were demographic and contextual and measured with closed and open-ended questions.

\section{Analysis and measurement tests}

Apart from basic descriptive statistics, we employed confirmatory factor analysis (CFA) to evaluate the factor structure of the dualistic passion model using the SPSS and AMOS 18.0 programs. The CFA permits testing of hypotheses that have a relationship between the observed variables (such as dualistic passion items) and the underlying latent constructs (harmonious and obsessive passion), as suggested by Vallerand et al. (2003). The 12 passion subscale items were used as indicators of Vallerand et al.'s (2003) two first-order latent factors, entitled harmonious and obsessive passion. To assess whether the tested model demonstrated a 'good fit' to the data set, we used the comparative fit index (CFI) and the root mean square error of approximation (RMSEA).

In order to evaluate the effects of contextual factors and experience on harmonious and obsessive passion for the job, we conducted a one-way analysis of variance (t-test and 
ANOVA, followed by post-hoc Sheffe analysis when significant differences occurred) with the five following independent variables: type and size of the sport organisation and years of experience in the current job, in the specific sport organisation, and in the sport industry generally. Additional demographic questions concerning age, gender, and education showed no significance, which suggests that the construct of passion is not related to these variables.

\section{Results}

\section{Demographics}

Respondents held a diversity of roles and positions within their organisation at strategic (e.g. Chief Executive Officer; Chief Operating Officer; Director; Head etc.), managerial (Regional Manager; Operations Manager; Community Manager; Stadium Manager; Marketing Manager; HR Manager), and administrative (Community officer; Sport Participation officer; Events and Hospitality officer; Commercial and Retail officer) levels. Table 1 depicts the profile of respondents. Among the 177 respondents, 138 (78 percent) were male; 71 (40.1 percent) were under the age of 30,72 (40.7 percent) between 31 and 45, and 34 (19.2 percent) were 46 or older. Ninety-five respondents (53.7 percent) held an undergraduate degree, 14 (7.9 percent) had a secondary education, 33 (18.6 percent) held an associate degree, and 35 (19.7 percent) had a postgraduate degree. One hundred and seventeen $(66.1 \%)$ respondents had more than six years of experience in the sport industry. Sixty respondents (33.9 percent) had more than six years of experience in the same organisation in which they were surveyed, and 44 (24.9 percent) had more than six years of experience in their current role.

INSERT TABLE 1 ABOUT HERE 
Overall, the study's findings indicated that administrative personnel in the British football sector consider their work to be a passionate activity, with a mean score of $4.21(\mathrm{SD}=.78)$. The following two sub-sections offer a more detailed account of this finding.

\section{INSERT TABLE 2 ABOUT HERE}

\section{Exploring the factorial validity of the dualistic passion model (CFA)}

First the two-correlated-factor model was tested in the total sample with harmonious and obsessive passion items loaded onto different factors; the results showed an unacceptable fit $(\chi 2 /$ d.f. $=3.49, \mathrm{CFI}=.80, \mathrm{RMSEA}=.10$; see Table 2$)$. Examination of the standardized factor loadings and standardized residuals (error terms) revealed that four items demonstrated poor loadings (below 0.45) to their respective latent variables; therefore, we decided to exclude these for further analysis (Mullan, Markland, \& Ingledew, 1997). Two of the four items were related to harmonious and the other two to obsessive passion. The harmonious related items were 'This job is a passion that I manage to control' and 'My job is in harmony with other things that are part of $m e$ '. The obsessive passion items were 'I have difficulties controlling my urge to do my job' and 'If I could, I would only do my job'.

After deleting the particular items, we again applied the CFA to the revised eight-item solution, producing an improved fit to the dataset (see Table 2). The ratio of $\chi^{2}$ to the degree of freedom $\left(\chi^{2} / \mathrm{df}=1.56\right)$ and the remaining commonly used goodness-of-fit indices $(\mathrm{CFI}=.97$, RMSEA=.05) were in line with the recommended criteria (Hu \& Bentler, 1999; Kline, 2005). As indicated in Table 3, factor loadings were comparably high and statistically significant, ranging from 0.46 to 0.71 , which is in accordance with the adequacy of the fit indices and supported the hypothesised structure of the dualistic passion model (Vallerand et al., 2003) in the examined organisational setting. Based on Fornell and Larcker (1981), factor 
loadings $>0.4$ that are statistically significant are proof of the convergent validity of the latent constructs, in this case the harmonious and obsessive passion dimensions.

\section{INSERT TABLE 3 ABOUT HERE}

Convergent validity refers to how well a set of items measures the dimension it was designed to measure. As such, harmonious and obsessive passion were correlated $(r=.23, p<.001)$ as suggested in previous studies (Mageau, Carpentier, \& Vallerand, 2011; Forest et al., 2011). This low correlation $(<.30)$ between the two dimensions confirmed the discriminant validity, which refers to whether two constructs are different from each other (Kline, 2005).

In order to further explore the dualistic structure of the passion model, we tested a one-factor model with all individual items loaded on a single passion factor. The results showed a low fit for the one-factor model, which further indicated that the dualistic passion model had a reasonably good fit to the 'parent' clubs-related dataset and a good fit to the foundations-related dataset (see Table 3). In summary, the factorial assessment of the dualistic passion model indicates a satisfactory fit for the data. Based on the CFA results, the aggregate mean was $3.95(\mathrm{SD}=.55)$ for harmonious passion and $2.28(\mathrm{SD}=.72)$ for obsessive passion, with acceptable Cronbach's alphas of 0.66 and 0.70 , respectively.

\section{Exploring effects on passion toward the job}

We used t-test and ANOVA to determine the effect of contextual variables on passion for the job. The results (see Table 4) indicated that the type of organisation had an effect on both harmonious and obsessive passion of employees. Employees who worked for charitable foundations were slightly more harmoniously passionate $(\mathrm{M}=4.08, \mathrm{SD}=.49)$ toward their job 
than those who worked for the 'parent' football clubs $(\mathrm{M}=3.82, \mathrm{SD}=.61)$; the mean difference was statistically significant $(t(175)=.46, p<.01)$. A similar difference was found for obsessive passion toward the job between club and foundation employees $(t(175)=8.03$, $p<.01$ ). However, the employees reported low overall average levels of obsessive passion toward their job in both organisational contexts.

\section{INSERT TABLE 4 ABOUT HERE}

These results suggest that organisation size does not affect the levels of either harmonious $(F(2,174)=1.67 p>.05)$ or obsessive passion $(F(2,174)=2.04 p>.05)$ among employees; the level of harmonious and obsessive passion reported by employees working for larger or smaller organisations (of either type) was comparable. Also, experience levels in the current job or the organisation did not seem to influence harmonious or obsessive passion among employees. Conversely, people who had worked for more than a year in the sport industry were more likely to report higher levels of obsessive passion than those who worked for a year or less $(F(2,174)=.3 .90 . p<.05)$, although this result did not apply to harmonious passion $(F(2,174)=.01 p>.05)$. As shown in Table 4, staff with a year or less of experience in the sport industry reported very low levels of obsessive passion towards their work $(M=1.89$, $\mathrm{SD}=.63)$ compared with respondents with two to five years $(\mathrm{M}=2.48, \mathrm{SD}=.82)$ and six years or more of experience $(\mathrm{M}=2.36, \mathrm{SD}=.71)$. Significant differences $(p<.05)$ were found in the mean results for early-career employees (up to a year of experience in the sport industry) versus those with two to five years of experience, and between early-career employees and those with six and more years of experience. 


\section{Discussion and theoretical contributions}

The main purpose of this study is to examine whether and in what type passion manifests in sport organisations' workforce. To date, sport management scholars have focused on a fairly wide number of job-related constructs, but passion has not been part of this research agenda. The present study is the first to draw on SDT to apply the DMP (Vallerand et al., 2003) within the workplace setting of sport organisations. Our results have failed to confirm the 12 item passion scale proposed by Vallerand et al. (2003) and yielded a two factor model with eight items to measure the passion at a sport-oriented workplace (see RQ 1). Generally, it is anticipated that different contexts may uncover slightly revised passion scales. The particular result (two factor solution with 8 items) has shown the importance of further exploring the applicability of a passion measure with modifications pertinent to sport jobs and activities (Vallerand et al., 2007; Vallerand and Houlfort, 2003; Stenserng, 2008). Indeed, with as many as 84.7 percent of participants stating that their job is a passion for them, the present study provides strong empirical support for Todd and Kent's (2009) proposition that employees in the sport industry may exhibit some distinctive psychologically-related traits. Given that previous research has suggested that many people identify themselves with the object of their passion (Murnieks, Mosakowski, \& Cardon, 2014; Vallerand \& Houlfort, 2003), one could argue that participants here are passionate about their job, which seems to have become part of their identity. This finding adds to empirical evidence from recent studies (e.g., Oja et al., 2015; Swanson \& Kent, 2015) that employees' identification in the sport industry is not restricted to the team, but extends to the organisation itself. However, the finding that workforce demonstrates a high level of passion implies that these employees do not only identify with the organisation when it is contextually salient to do so (Tajfel \& Turner, 1986), but instead (or as well) with the very specific job-related task because they can 
both pursue it and see its importance at all times (Houlfort et al., 2015; Lavigne, Forest, Fernet, Crevier-Braud, 2015).

Furthermore, although the general assumption that employees in sport organisations are passionate about their jobs has not hitherto been empirically confirmed, it was the application of DMP (Vallerand et al., 2003) that enabled us to theoretically advance our understanding on work-related constructs, thereby identifying the effects of harmonious and obsessive passion. More specifically, the present study reveals that employees in sport organisations show high levels of harmonious passion and low levels of obsessive passion (see RQ1a). This result supports findings from empirical studies outside the sport management literature that put forward that an employee may have one type of passion but not the other (Ho et al., 2011). As such, employees in sport organisations seem to undertake their jobs freely and voluntary because they see it as important and not solely because they seek social approval or recognition (Vallerand \& Houlfort, 2003). However, despite their low level of obsessive passion, employees appreciate the obsessiveness their job can generate; that is, the need to self-validate and garner social approval through participation in the beloved activity (Curran et al., 2015). In general, though, employees' passion does not control them and is not an obsession that can conflict with other aspects of their life (Ho et al., 2011).

It is noteworthy that recent empirical research has shown the positive 'face' of the 'dark side' (sic) of passion (Patel et al., 2015; Omorede, Thorgren, \& Wincent, 2013), proposing that leaders who score high in obsessive passion are likely to excel in highly dynamic environments. If one accepts that management of football occurs in a setting characterized by high degree of unpredictability and uncertainty (Hamil \& Chadwick, 2010), then having obsessively passionate employees may lead to better organisational performance. 
It is interesting to see, however, that despite the apparent pressures to perform by (potentially) mitigating various types of uncertainty (Deci \& Ryan, 1987), administrative employees in the 'parent' companies still demonstrate low levels of obsessive passion. It is interesting to see, however, that despite the apparent pressures to perform by (potentially) mitigating various types of uncertainty (Deci \& Ryan, 1987), administrative employees in the 'parent' companies still demonstrate low levels of obsessive passion. In general, however, the high level of harmonious passion, in conjunction with low level of obsessive passion that employees demonstrate, may further suggest beneficial effects on their ability to deliver their task and other work-related activities, by improving work satisfaction (Thorgren et al., 2013) and/or preventing burnout (Carbonneau et al., 2008; Danylchuk, 1993; Lavigne, Forest, \& Crevier-Braud, 2012; Vallerand et al., 2010). Although further research is needed to empirically test whether this is actually the case, this study shows that working in the sport industry constitutes a harmoniously passionate activity, which can partially explain why paid jobs in sport have been (Parks \& Para, 1994) and remain desirable (Sibson, 2010; Todd \& Andrew, 2008).

Another contribution of this study pertains to the fact that it broadens the theoretical discussion in formal members of two 'divisions' (see Swanson \& Kent, 2015), thereby offering insights from organisational actors who represent two different, yet interconnected, institutional logics (see RQ 2). Our data analysis highlighted that the type of job associated with the divisional scope and purpose within sport organisations does have an effect on both the harmonious and obsessive passion experienced by personnel therein. As such, the present study extends relevant literature that has been limited in conceptualizing work passion for a job as a whole (e.g., Ho et al., 2011), and has therefore failed to examine the possibility that individuals may have different types of passion about different jobs within divisional units of the same organisational entities (in our case, professional sport). 
A likely explanation for the slight difference on harmonious passion between employees in the two examined settings is that these organisations carry different (institutional) logics and that personnel's job-related tasks differ a great deal as a result. On the one hand, and through various community projects, foundations' employees strive for higher-order goals (see logic of 'idealism') such as improving health, educating children, increasing sport participation, and seeking social cohesion. On the other hand, business executives - who are perhaps closer to the logics of 'entrepreneurialism' and 'managerialism' (Gammelsæter, 2010) - seem to be passionately driven towards making a 'profit' (Garciadel-Barrio \& Szymanski, 2009; Millward, 2013), which can contribute to the core business of the football company; that is, on-field success while remaining financially solvent. Therefore, we have assumed that employees in the charitable foundations may see the joy of engaging in the work for its own sake (through having an impact on people's lives) more than their counterparts in the 'parent' companies, whose focus is often on tasks like achieving better sponsorship deals or hospitality packages and contributing towards effective communication strategies. After all, the latter's income is usually based on monetary incentives and pay-forperformance schemes, similar to business personnel in other industries (Cadsby, Song, \& Tapon, 2007).

Moreover, the nature of the work of the charitable foundations' technical core entails loads of 'outside-the-office' tasks. These tasks are often not limited to either the football club's imperatives (such as creating a new generation of fans or the engagement thereof) or the sport of football alone (that is, using a multi-sport platform to 'do' the job). This "allembracing passion" (Anagnostopoulos et al., 2014, p. 274), which may also highlight the interplay of work and non-work arrangements (Brown et al., 2011) by blurring the classic dichotomy between work and leisure (Filho, 2010), seems to further disconnect the job from any derived feelings of social approval or recognition (see obsessive passion). Instead, the 
foundation employees feel even freer to pursue their job than their counterparts in the 'parent' companies.

The above finding may be of particular importance when considering the complex environment in which these charitable foundations exist and operate. Indeed, a combination of factors form a complex environment consisting of different 'job tasks', which may make these employees feel bound to pursue various job-related actions. These factors are (a) the increasing recognition football foundations enjoy from external organisations for the effectiveness of their delivery (Walters \& Panton, 2014), (b) their over-reliance on public funding (Bingham \& Walters, 2013), (c) their continuous efforts towards capacity building through partnerships with often heterogeneous stakeholder groups for the implementation of community programs (Heinze, Soderstrom, \& Zdroik, 2014; Kihl, Babiak \& Tainski, 2014), and (d) the need to counteract any negative connotations that the current football context possesses, in an endeavour to 'get the balance right' (Slack \& Shrives, 2008). Rather than being seen as 'free' or 'voluntary' undertakings, such actions are instead motivated by a compulsion to maintain the business and socially-related acceptance resulting from the job (that is, an obsessive type of passion). The personnel therein is faced with such controversies as well as various types of interdependences, which is a typical situation in complex environments (Child, 1972; Miller, 1988). Despite that, the evidence offered in the present study that employees demonstrate high harmonious passion should be perceived as an encouraging outcome, especially considering studies that have shown that better performance can be achieved by harmoniously passionate employees under high environmental complexity (Patel et al., 2015).

Therefore, in accordance with arguments made elsewhere (e.g., Allenbaugh, 2002; King, 2005), emotions can be instrumental and useful within an organisation only if they help 
achieve a 'rational' goal, whether it is business-oriented or socially-oriented. In this context, a goal is considered rational when the employee performs actions that constitute the most effective and efficient means of bringing them closer to achieving the organisational objectives. In this regard, workforce within the charitable foundations demonstrates a harmonious passion that, when built around broader personal social consciousness stimuli, helps their organisations grow and secure returns to 'investors'; that is, statutory funders, commercial partners, and the parent football club itself. Indeed, Zigarmi and Nimon (2011) argued that "the essence of work passion is the intention to act consistently using behaviours that are constructive for the organisation's desired outcomes as well as the individual's" (p. 451).

With regard to those contextual elements that may influence the type of passion experienced by those who work in sport organisations (see RQ 3), the results of the present study suggest that although generally employees show low level of obsessive passion, this is largely influenced by their experience in the industry. Early-career individuals have much lower levels of obsessive passion than employees with two or more years of experience in the sport industry. This challenges the view that entry-level positions in sport often involve working unsociable hours and frequently entail 'heavy competition' (Emery, Crabtree, \& Kerr, 2012). What becomes evident, however, is that once individuals have acquired some experience (i.e., more than one year at their role), they start becoming more obsessively passionate about their work (but the level of passion remains 'low'); this is the case across both types of the organisations under examination. Employees who gain experience within the same organisation or in relation to a specific task (job title) are not more obsessively passionate than those who gain experience in different jobs and/or organisations. This is an encouraging finding for the field of sport, considering that previous studies have suggested that obsessive passion creates activity addiction (Stenseng, 2008) or emotional exhaustion 
(Lavigne et al., 2012). At the same time, the level of harmonious passion does not differ significantly with the level of experience. This is a very important finding since employees in football organisations (of either type) seem to demonstrate a harmonious passion throughout their career. This echoes what person-environment fit literature advocates (e.g., Edwards, 2008; Kristof, 1996); that an individual's passion is attained through finding a fit with the right work. As Chen, Ellsworth and Schwarz (2015) empirically show, however, passion for work can be also cultivated over time in any line of work, thereby developing one's passion through mastery rather than expecting it from the outset. Identifying which one of the two processes occur in the context of sport would partially explain the increasing desire of young people to find employment in the sport industry (Sibson, 2010).

\section{Practical implications}

This study has several implications for practice. First, the key finding that sport organisations yield a high level of harmonious passion and a low level of obsessive passion clearly indicates that the particular working environment attracts and/or facilitates employees to experience a positive work-life balance and a voluntary internalization of the job, while obsessive passion is somehow mitigated. The reality is that sport organisations exist and operate in a highly dynamic and complex environment with a range of pressures and external contingencies attached to job tasks. This may indicate that further nurturing the employees' harmonious passion for their job (especially after some years of experience in the sport industry) is a challenge in itself. Previous research suggests that empowering employees to work autonomously, redesigning the job to be more meaningful and inspiring, and providing feedback can contribute to how employees valuate their job and become passionate (Vallerand \& Houlfort, 2003). An equally effective way could be to introduce mentoring and continuing professional development (CPD) schemes, delivered by employees who are experienced and - crucially - harmoniously passionate (Thorgren et al., 2013). The 
underlying message of such schemes could perhaps be drawn on sport-focused analogies that stretch the importance of notions such as harmony, balance, and team spirit, but also underscore the importance of playing for the love of the game, regardless of what spectators may say afterwards about individual performances (that is, ignoring outcomes and the rewards attached to them).

Another implication for practice can be drawn directly from the confirmation of the dualistic model of passion in the sport organisational environment. Given that passion and motivation for work are two differentiated theoretical concepts that have significant affective, cognitive, and behavioural effects, sport managers - especially those involved in human resource practices - should seriously consider incorporating the concept of passion in the recruitment and selection procedures of new employees. The empirical findings offered strong evidence that practitioners can use the particular dualistic passion measure as a valid and reliable evaluation tool, not only for identifying potential passionate employees, but also for differentiating between harmonious and obsessive candidates. Considering that obsessive employees are often associated with negative cognitive consequences, screening candidates in early stages can help to create and maintain a workforce with a high level of harmonious passion. This is especially important for charitable sport organisations, which are asked to excel towards both social and business-related objectives (Anagnostopoulos et al., 2014), despite their arguable shortage of resources, including personnel (Bingham \& Walters, 2013). Therefore, managers need to be more "frugal and wise with their decisions as they seek to recruit, foster and retain qualified and motivated personnel" (Zigarmi et al., 2009, p. 301), an attitude that it is hoped will help them perform the tasks for which they have been assigned responsibility with harmonious passion. 


\section{Limitations and future research}

The present research has some limitations that offer avenues for future research. First, our inferences could be affected by the geographical context in which the study was carried out. Football clubs in the UK, not least their established charitable foundations, are becoming increasingly professionalized and commercialized, which means that the present findings are not necessarily generalizable to other organisations from different sports, or even from other countries and/or continents. Consequently, the current set of results needs further replication and validation with different samples (perhaps less-popular sports) across different geographical settings (such as North America or Australasia) in order to achieve greater generalizability and confidence in the findings.

Another limitation pertains to our partial assessment of passion within the workplace setting of sport organisations. This is because the exploratory nature of this study did not make it possible to establish any sort of causality between other job-related constructs. To this end, further research could investigate whether the slightly higher level of harmonious passion shown, for example, by charitable foundation staff is also related to a high level of commitment and/or identification to the organisation. In other words, would an individual show different level and/or different type of passion (harmonious/obsessive) doing the same job in another organisation (that is, passion for the job itself and passion for the job in that organisation). As such, further research could investigate whether team sport organisation employees are passionate fans (and what type of passion they demonstrate) of the team they are working for and if any transfer of passion is occurring (that is, towards a 'dual passion'). It would also be useful to examine whether passion and CPD have an effect on work satisfaction in the organisational setting of sport organisations, considering that performance (an organisation-centred construct) and satisfaction (an employee-centred construct) can both offer a sound picture of outcomes in the workplace. 
There are also limitations at the methodological level. Specifically, the survey sample is limited compared to the number of potential respondents. As such, there might be a difference between what respondents answered and what non-respondents would have answered (that is, non-response error; see Podsakoff, MacKenzie, Lee, \& Podsakoff, 2003). However, we are confident we have obtained a sufficient and reliable number of respondents to measure the scale of passion, which has been used and validated in numerous previous studies.. Further, the passion scale was operationalized in compliance with Vallerand et al. (2003) who suggest a Likert type scale asking the respondents to state their degree of agreement in predefined statements. This process allows for cross-sectional analysis in order to compare respondents' level of passion, but might have restricted any nuanced responses. All methodological issues considered, a qualitative in nature and longitudinal study can offer a richer account of how passion unfolds over time, its antecedents and the contextual factors that may have a bearing on the type of passion experienced by employees in sport organisations.

\section{Conclusion}

The central purpose of this study was to examine psychological construct passion in the context of sport organisations. Therefore, this is the first sport management study to empirically show that passion exists amongst administrative personnel. In fact, employees within sport organisations demonstrate high levels of harmonious passion and low levels of obsessive passion, and do so throughout their career and irrespective of their job portfolios and work-related agendas. Interestingly, however, employees who engage with community and outreach-related tasks demonstrate even higher (albeit slightly) levels of harmonious passion. This is further testimony to how the 'magnitude' and 'power' of sport, and football in particular, can impact not just on the community programs' beneficiaries, but also on the 
'agents' responsible for delivering such related job-tasks. Additional research is greatly needed in order to better understand the intricacies underlying the role of passion in sport professionals. We hope that the present study helps to provide a foundation that will facilitate just that.

\section{References}

Allenbaugh, E. (2002). Deliberate Success: Realise your vision with purpose, passion, and performance. New Jersey: Warner Books.

Anagnostopoulos, C., \& Shilbury, D. (2013). Implementing corporate social responsibility in English football: towards multi-theoretical integration. Sport, Business and Management: An International Journal, 3(4), 268-284.

Anagnostopoulos, C., Byers, T., \& Shilbury, D. (2014). Corporate social responsibility in team sport organisations: toward a theory of decision-making. European Sport Management Quarterly, 14(3), 259-281.

Anderson, N. (1995). Work with passion: How to do what you love for a living. San Rafael, CA: New World Library.

Ashforth, B.E., \& Mael, F. (1989). Social identity theory and the organisation. Academy of Management Review, 14(1), 20-39.

Babiak, K., \& Wolfe, R. (2009). Determinants of corporate social responsibility in professional sport: Internal and external factors. Journal of Sport Management, 23(6), 717742.

Balon, S., Lecoq, J., \& Rimé, B. (2013). Passion and personality: Is passionate behaviour a function of personality?. Revue Européenne de Psychologie Appliquée/European Review of Applied Psychology, 63(1), 59-65.

Bingham, T., \& Walters, W. (2013). Financial sustainability within UK charities: Community sport trusts and corporate social responsibility partnerships. VOLUNTAS: International Journal of Voluntary and Nonprofit Organisations, 24(3), 606-629.

Birkeland, K.I, \& Buch, R. (2015). The dualistic model of passion for work: Discriminate and predictive validity with work engagement and workaholism. Motivation and Emotion, 39(3), 392-408. DOI: 10.1007/s11031-014-9462-x

Boyatzis, R., McKee, A., \& Goleman, D. (2002). Reawakening your passion for work. Harvard Business Review, 80, 87-94.

Brown, K., Bradley, L., Lingard, H., Townsend, K., \& Ling, S. (2011). Labouring for leisure? Achieving work-life balance through compressed working weeks. Annals of Leisure Research, 14(1), 43-59. doi: 10.1080/11745398.2011.575046 
Bruch, H., \& Ghoshal, S. (2003). Unleashing organisational energy. MIT Sloan Management Review, 45, 45-51.

Cadsby, C.B., Song, F., \& Tapon, F. (2007). Sorting and incentive effects of pay for performance: An experimental investigation. Academy of Management Journal, 50(2), 387405.

Carbonneau, N., Vallerand, R. J., Fernét, C., \& Guay, F. (2008). The role of passion for teaching in intrapersonal and interpersonal outcomes. Journal of Educational Psychology, 100(4), 977-987.

Cardon, M., Wincent, J., Singh, J., \& Drnovsek, M. (2009). The nature and experience of entrepreneurial passion. Academy of Management Review, 34, 511-532.

Cave, A. (2015). The potential of sport: A $£ 20$ billion industry. The Telegraph. Retrived from http://www.telegraph.co.uk/sponsored/business/business-sport-series/11604008/potential-ofsport-20billion-industry.html. (May 13).

Caudroit, J., Boiché, J., Stephan, Y., Le Scanff, C., \& Trouilloud, D. (2011). Predictors of work/family interference and leisure-time physical activity among teachers: The role of passion towards work. European Journal of Work and Organisational Psychology, 20, 326344. doi: 10.1080/13594320903507124

Chang, J.Y., Choi, J.N., \& Kim, M.U. (2008). Turnover of highly educated R\&D professional: The role of pre-entry cognitive style, work values and career orientation. Journal of Occupational and Organisational Psychology, 81, 299-317.

Chang, K., \& Chelladurai, P. (2003). System-based quality dimensions in fitness services: development of the scale of quality. The Service Industries Journal, 23(5), 65-83.

Chelladurai, P., \& Ogasawara, E. (2003). Satisfaction and commitment of American and Japanese collegiate coaches. Journal of Sport Management, 17, 62-73.

Chen, P., Ellsworth, C.P., \& Schwarz, N. (2015). Finding a fit or developing it: Implicit theories about achieving passion for work. Personality and Social Psychology Bulletin, 41(10), 1411-1424. DOI: 10.1177/0146167215596988.

Child, J. (1972). Organisational structure, environment and performance: the role of strategic choice. Sociology, 6, 1-22.

Cleave, S. (1993). Applicability of job diagnostic survey to administrative positions in university physical education and sport. Journal of Sport Management, 7(2), 141- 150.

Cunningham, B.G., Sagas, M., Dixon, M., Kent, A., \& Turner, A.B. (2005). Anticipated career satisfaction, affective occupational commitment, and intentions to enter the sport management profession. Journal of Sport Management, 19, 43-57.

Cunningham, B. G., \& Sagas, M. (2004) Work experiences, occupational commitment, and intent to enter the sport management profession. Physical Educator, 61(3), 146-156. 
Curran, T., Hill, P.A., Appleton, R.P., Vallerand, J.R., \& Standage, M. (2015). The psychology of passion: A meta-analytical review of a decade of research on intrapersonal outcomes. Motivation and Emotion, 39(5), 631-655. DOI: 10.1007/s11031-015-9503-0

Danylchuk, K. (1993). The presence of occupational burnout and its correlates in university physical education personnel. Journal of Sport Management, 7, 107-121.

Day, V.D., Gordon, S., \& Fink, C. (2012). The Sporting life: Exploring organisations through the lens of sport. The Academy of Management, 6(1), 397- 433.

Deci, E.L., \& Ryan, R.M. (1985). Intrinsic motivation and self-determination in human behaviour. Plenum, New York.

Deci, E.L., \& Ryan, R.M. (1987). The support of autonomy and the control of behaviour. Journal of Personality and Social Psychology, 53, 1024-1037.

Deci, E.L., \& Ryan, R.M. (1994). Promoting self-determined education. Scandinavian Journal of Educational Research, 38, 3-14.

Deci, E.L., \& Ryan, R.M. (2000). The "what" and "why" of goal pursuits: Human needs and the self-determination of behaviour. Psychological Inquiry, 11, 227-268.

Dixon, M.A., \& Warner, S. (2010). Employee satisfaction in sport: Development of a multidimensional model in coaching. Journal of Sport Management, 24, 139-168.

Doherty, A.J. (1998). Managing our human resources: A review of organisational behaviour in sport. Sport Management Review, 1, 1-24.

Donahue, E.G., Rip, B., \& Vallerand, R.J. (2009). When winning is everything: On passion and aggression in sport. Psychology of Sport and Exercise, 10, 526-534.

Eagly, A.H., \& Chaiken, S. (1993). The psychology of attitudes. Fort Worth, TX: Harcourt Brace Jovanovich.

Edwards, J.R. (2008). Person-Environment Fit in organizations: An assessment of theoretical progress. The Academy of Management Annals, 2, 167-230.

Emery, P., Crabtree, R., \& Kerr, A. (2012). The Australian sport management job market: an advertisement audit of employer need. Annals of Leisure Research, 15(4), 335-353, doi: $10.1080 / 11745398.2012 .737300$

Ferreira, R.R. (1988). Effect of work shift and club size on employees. Journal of Sport Management, 2, 1-13.

Filho, S.C. (2010). Rafting guides: Leisure, work and lifestyle. Annals of Leisure Research, 13(1-2), 282-297. doi:10.1080/11745398.2010.9686848 
Forest, J., Mageau, G.A., Sarrazin, C., \& Morin, E.M. (2011). 'Work is my passion': The different affective, behavioural, and cognitive consequences of harmonious and obsessive passion toward work. Canadian Journal of Administrative Sciences, 28, 17-30.

Fornell, C., \& Larcker, F.D. (1981). Evaluating structural equation models with unobservable variables and measurement error. Journal of Marketing Research, 18, 39-50.

Freidson, E. (2001). Professionalism: The third logic. Cambridge: Polity Press.

Gagné, M., \& Deci, E.L. (2005). Self-determination theory and work motivation. Journal of Organisational Behaviour, 26, 331-362.

Gammelsæter, H. (2010). Institutional pluralism and governance in 'commercialised' sport clubs. European Sport Management Quarterly, 10(5), 569-594.

Garcia-del-Barrio, P., \& Szymanski, S. (2009). Goal! Profit maximization versus win maximization in football. Review of Industrial Organisation, 34(1), 45-68. doi: 10.1007/s11151-009-9203-6.

Gielnik, M. M., Spitzmuller, M., Schmitt, A., Klemann, D. K., \& Frese, M. (2015). I put in effort, therefore I am passionate: Investigating the path from effort to passion in entrepreneurship. Academy of Management Journal, 58(4), 1012-1031.

Hall, A.S., Bowers, G.A., \& Martin, L.C. (2010). An exploratory study of job satisfaction levels of athletic marketing directors at national collegiate athletic association (NCAA) division I-A institutions. International Journal of Sport Management Recreation \& Tourism, 6, 1-17. doi: 10.5199/ijsmart-1791-874X-6a

Hamil, S., \& Chadwick, S. (2010). Managing football: An international perspective. Oxford: Butterworth-Heinemann.

Hassan, D. (2012). The social and cultural management of sport: Contemporary arguments concerning the case for specificity. In L. Trenberth, \& D. Hassan (Eds.) Managing sport business: An introduction, (pp. 32-46). London: Routledge.

Heinze, L.K., Soderstrom, S., \& Zdroik, J. (2014). Toward strategic and authentic corporate social responsibility in professional sport: A case study of the Detroit Lions. Journal of Sport Management, 28, 672-686 http://dx.doi.org/10.1123/JSM.2013-0307

Ho, V.T., Wong, S., \& Lee, C.H. (2011). A tale of passion: Linking job passion and cognitive engagement to employee work performance. Journal of Management Studies, 48, 26-47.

Hodgins, H.S., \& Knee, R. (2002). The integrating self and conscious experience. In E.L. Deci, \& R.M. Ryan (Eds.), Handbook on self-determination research: Theoretical and applied issues (pp. 87-100). Rochester, NY: University of Rochester Press.

Houlfort, N., Fernet, C., Vallerand, J.R., Laframboise, A., Guay, F., \& Koestner, R. (2015). The role of passion for work and need satisfaction in psychological adjustment to retirement. Journal of Vocational Behaviour, 88, 84-94. doi:10.1016/j.jvb.2015.02.005. 
Houlfort, N., \& Vallerand, R. J. (2006). La passion envers le travail: les deux côtés de la médaille. [Passion at work : the two sides of the medal] Revue Muldisciplinaire sur l'Emploi, le Syndicalisme et le travail, 2, 4-17.

Hu, L., \& Bentler, P.M. (1999). Cut off criteria for fit indexes in covariance structure analysis: Conventional criteria versus new alternatives. Structural Equation Modelling, 6(1), $1-55$.

Kanungo, R.N. (1979). The concepts of alienation and involvement revisited. Psychological Bulletin, 86(1), 119-138. http://dx.doi.org/10.1037/0033-2909.86.1.119

Kanungo, R.N. (1982). Measurement of job and work involvement. Journal of Applied Psychology, 67(3), 341-349. http://dx.doi.org/10.1037/0021-9010.67.3.341

Kent, A., \& Chelladurai, P. (2001). Perceived transformational leadership, organisational commitment and citizenship behaviour: A case study in intercollegiate athletics. Journal of Sport Management, 15(2), 135-159.

Kihl, L., Babiak, K., \& Tainsky, S. (2014). Evaluating the implementation of a professional sport team's corporate community involvement initiative. Journal of Sport Management, 28, 324-337. doi: http://dx.doi.org/10.1123/jsm.2012-0258

King, D. (2005). In pursuit of passion: A frame of analysis of the popular management literature. TASA Conference Proceedings. University of Tasmania, 6-8 December.

Kline, R.B. (2005). Principles and practice of structural equation modelling ( $2^{\text {nd }}$ Ed.). New York, NY: The Guilford Press.

Koehler, L.S. (1988). Job satisfaction and corporate fitness managers: An organisational behaviour approach to sport management. Journal of Sport Management, 2, 100-105.

Koestner, R., \& Losier, G.F. (2002). Distinguishing three ways of being internally motivated: a closer look at introjection, identification, and intrinsic motivation. In L.E. Deci, \& M.R. Ryan, (Eds), Handbook of Self-Determination Research (pp. 101-121). Rochester, NY: University of Rochester Press.

Kristof, A.L. (1996). Person-organization fit: An integrative review of its conceptualizations, measurement, and implications. Personnel Psychology, 49, 1-49.

Lavigne, L.G., Forest, J., Fernet, C., \& Crevier-Braud, L. (2012). Passion at work and burnout: A two-study test of the mediating role of flow experiences. European Journal of Work and Organisational Psychology, 21(4), 518-546. doi:10.1080/1359432X.2011.578390

Lavigne, L.G., Forest, J., Fernet, C., \& Crevier-Braud, L. (2015). Passion at work and workers' evaluations of job demands and resources: a longitudinal study. Journal of Applied Social Psychology, 44, 255-265. doi: 10.1111/jasp.12209

Mageau, A.G., Carpentier, J., \& Vallerand, J.R. (2011). The role of self-esteem contingencies in the distinction between obsessive and harmonious passion. European Journal of Social Psychology, 41, 720-729. doi: 10.1002/ejsp.798 
Marques, J.F. (2007). Leadership: emotional intelligence, passion, and...what else?. Journal of Management Development, 26, 644-651.

Melton, E.N., Cunningham, G.B. (2014). Who are the champions? Using a multilevel model to examine perceptions of employee support for LGBT-inclusion in sport organisations. Journal of Sport Management, 28(2), 189-206. doi:10.1123/jsm.2012-0086

Miller, D. (1988). Relating Porter's business strategies to environment and structure: analysis and performance implications. Academy of Management Journal, 31, 280-308.

Millward, P. (2013). New football directors in the twenty-first century: profit and revenue in the English Premier League's transnational age. Leisure Studies, 32(4), 399-414, doi:10.1080/02614367.2012.673130

Mintzberg, H. (1980). Structure in 5's: A synthesis of the research on organisation design. Management Science, 26(3), 322-341.

Moses, B. (2001). It's all about passion. Across the Board, 38(3), 55-58.

Mullan, E., Markland, D., \& Ingledew, D.K. (1997). A graded conceptualisation of selfdetermination in the regulation of exercise behaviour: Development of a measure using confirmatory factor analytic procedures. Personality and Individual Differences, 23, 745-752.

Murnieks, Y.C., Mosakowski, E., \& Cardon, S.M. (2014). Pathways of passion: Identity centrality, passion, and behaviour among entrepreneurs. Journal of Management, 40(6), 1583-1606. doi: 10.1177/0149206311433855

Neumann, A. (2006). Professing passion: emotion in the scholarship of professors at research universities. American Educational Research Journal, 43, 381-424.

Oja, B.D., Bass, J.R., \& Gordon, B.S. (2015). Conceptualizing employee identification with sport organisations: sport employee identification (SEI). Sport Management Review, in press http://dx.doi.org/10.1016/j.smr.2015.02.002

Omorede, A., Thorgren, S., \& Wincent, J. (2013). Obsessive passion, competence, and performance in a project management context. International Journal of Project Management, 31(6), 877-888. doi:10.1016/j.ijproman.2012.09.002

Parks, J.B., \& Para, L.F. (1994). Job satisfaction of sport management of alumnae/i. Journal of Sport Management, 8, 49-56. 
Parks, J.B. (1991). Employment status of alumni of an undergraduate sport management program. Journal of Sport Management, 5(2), 100-110.

Patel, C.P., Thorgren, S., \& Wincent, J. (2015). Leadership, passion and performance: A study of job creation projects during the recession. British Journal of Management, 26(2), 211-224. doi: 10.1111/1467-8551.12092

Perttula, K. H., \& Cardon, M. S. (2011). Passion. In K. S. Cameron \& G. M. Spreitzer (Eds.), The Oxford handbook of positive organizational scholarship (pp. 190-200). New York, NY: Oxford University Press.

Perrewé, L.P.,Hochwarter, A.W., Ferris, R.G.,, McAllister, P.C., \& Harris, N.J. (2014). Developing a passion for work passion: Future directions on an emerging construct. Journal of Organizational Behavior, 35, 145-150. DOI: 10.1002/job.1902

Philippe, F. L., Vallerand, R. J., Houlfort, N., Lavigne, G. L., \& Donahue, E. G. (2010). Passion for an activity and quality of interpersonal relationships: The mediating role of emotions. Journal of Personality and Social Psychology, 98, 917-932.

Podsakoff, P.M., MacKenzie, S.B., Lee, J., \& Podsakoff, N.P. (2003). Common method biases in behaviour research: A critical review of the literature and recommended remedies. Journal of Applied Psychology, 88(5), 879-903.

Ratelle, C. F., Vallerand, R. J., Mageau, G. A., Rousseau, F. L., \& Provencher, P. J. (2004). When passion leads to problematic outcomes. Journal of Gambling Studies, 25, 105-119.

Rip, B., Vallerand, J.R., \& Lafrenière, K.M-A. (2012). Passion for a cause, passion for a creed: On ideological passion, identity threat, and extremism. Journal of Personality, 80(3), 573-602. doi: 10.1111/j.1467-6494.2011.00743.x

Rousseau, F. L., \& Vallerand, R. J. (2008). An examination of the relationship between passion and subjective well-being in older adults. The International Journal of Aging and Human Development, 66, 195-211.

Ryan, R.M., \& Deci, E.L. (2000). Self-determination theory and the facilitation of intrinsic motivation, social development, and well-being. American Psychologist, 55, 68-78.

Shank, D.M, \& Lyberger, R.M. (2015). Sport marketing. A strategic perspective ( $5^{\text {th }}$ Ed.). Oxon: Routledge

Sibson R. (2010) Why event, sport, and recreation management? A western Australian study of undergraduate student degree choice. Annals of Leisure Research, 13(3), 376-394, doi: 10.1080/11745398.2010.9686854. 
Slack, R., \& Shrives, P. (2008). Social disclosure and legitimacy in Premier League football clubs: the first ten years. Journal of Applied Accounting, 9(1), 17-28. doi: $10.1108 / 09675420810886105$.

Smith, C.T.A, \& Stewart, B. (2010). The special features of sport: A critical revisit. Sport Management Review, 13, 1-13.

Stenseng, F. (2008). The two faces of leisure activity engagement: Harmonious and obsessive passion in relation to intrapersonal conflict and life domain outcome. Leisure Sciences, 30(5), $465-481$.

Swanson S, \& Kent, A. (2015). Fandom in the workplace: Multi-target identification in professional team sports. Journal of Sport Management, 29(4), 461-477. http://dx.doi.org/10.1123/jsm.2014-0132

Tajfel, H. (1978). Differentiation between social groups. London: Academic Press.

Tajfel, H., \& Turner, J.C. (1986). The social identity theory of intergroup behaviour. In S. Worchel, \& G.W. Austin (Eds), Psychology of Intergroup Relations, (pp. 7-24) (2 ${ }^{\text {nd }}$ Ed.). Nelson-Hall, Chicago, IL.

Thorgren, S., Wincent, J., \& Sirén, C. (2013). The influence of passion and work-life thoughts on work satisfaction. Human Resource Development Quarterly, 24(4), 469-492. doi: 10.1002/hrdq.21172

Todd, S., \& Kent, A. (2009). A social identity perspective on the job attitudes of employees in sport. Management Decision, 47(1), 173-190.

Todd, S.Y., \& Andrew, D. (2006). The role of satisfying tasks and organisational support in the job attitudes of sporting goods retail employees. International Journal of Sport Management and Marketing, 1(4), 378 - 389.

Todd, S.Y., \& Andrew, D. (2008). An exploratory investigation of sport management students' attraction to sport jobs. International Journal of Sport Management and Marketing 4(4), 323-337

Turner, B.A., \& Chelladurai, P. (2005). Organisational and occupational commitment, intention to leave and perceived performance of intercollegiate coaches. Journal of Sport Management, 19, 193-211.

Vallerand, R. J. (2015). The psychology of passion: A dualistic model. New York: Oxford.

Vallerand, R.J. (2010). On passion for life activities: The dualistic model of passion. In M.P. Zanna (Ed.), Advances in experimental social psychology (pp. 97-193). New York: Academic Press.

Vallerand, R.J., Blanchard, C., Mageau, G.A., Koestner, R., Ratelle, C., Léonard, M., Gagné, M., \& Marsolais, J. (2003). Les passions de l'âme: On obsessive and harmonious passion. Journal of Personality and Social Psychology, 85, 756-767. 
Vallerand, R.J., Mageau, G.A., Elliot, A.J., Dumais, A., Demers, M., \& Rousseau, F. (2008). Passion and performance attainment in sport. Psychology of Sport and Exercise, 9, 373-392.

Vallerand, R.J., Paquet, Y., Philippe, F.L., \& Charest, J. (2010). the role of passion for work in burnout: A process model. Journal of Personality, 78, 289-312.

Vallerand, R.J., Salvy, S., Mageau, G.A., Elliot, A.J., Denis, P.L., Grouzet, F.M.E., \& Blanchard, C. (2007). On the role of passion in performance. Journal of Personality, 75, 505533.

Vallerand, R.J., \& Houlfort, N. (2003). Passion at work: Toward a new conceptualization. In D. Skarlicki, S. Gilliland, \& D. Steiner (Eds.), Research in social issues in management, (pp. 175-204). Greenwich, CT: Information Age Publishing Inc.

Wakefield, K. (2016). Using fan passion to predict attendance, media consumption and social media behaviors. Journal of Sport Management, forthcoming.

Walters, G., \& Panton, M. (2014). Corporate social responsibility and social partnerships in professional football. Soccer \& Society 15(6), 828-846, http://dx.doi.org/10.1080/14660970.2014.920621

Wann, D.L, \& Branscombe, N.R. (1993). Sports fans: Measuring degree of identification with their team. International Journal of Sport Psychology, 24, 1-17.

Zigarmi, D, Nimon, K., Houson, D., Witt, D., \& Diehl, J. (2009). Beyond engagement: Toward a framework and operational definition for employee work passion. Human Resource Development Review, 8(3), 300-326.

Zigarmi, D., \& Nimon, K. (2011). A Cognitive approach to work intention: The stuff that employee work passion is made of? Advances in Developing Human Resources, 13(4), 447461. 